\title{
The Impact of Government Support Initiatives on the Growth of Female Businesses in Tshwane South Africa
}

\author{
Magaret Phillips \\ M Phil student in Entrepreneurship: University of Pretoria \\ Email:phillmj@unisa.ac.za \\ Menisha Moos \\ Lecturer: University of Pretoria \\ Email:menisha.moos@up.ac.za \\ Prof G. Nieman \\ Professor: University of Pretoria \\ Email: ghnieman@up.ac.za
}

Doi:10.5901/mjss.2014.v5n15p85

\begin{abstract}
Previous research has shown that small business growth may be the consequence of various factors. Entrepreneurs face various challenges in the growth of their businesses. A lack of support and general resources are some of the challenges they face. This causal research study explored the impact that the use of government support initiatives has on the growth of the businesses of female entrepreneurs in Tshwane South Africa. A quantitative study was done and a sample of 111 female entrepreneurs participated in this study. Data were obtained by means of structured questionnaires administered via a webbased survey. The data were subjected to descriptive and inferential statistical analysis. The findings clearly indicate that despite these entrepreneurs getting any assistance from government institutions their businesses showed growth. The findings of this study may be extended to government support institutions so that they can improve the quality design and cost effectiveness of support services.
\end{abstract}

Keywords: Government support, entrepreneurship, female entrepreneurs, sme growth,

\section{Introduction}

Poverty, inequality and unemployment have been identified as the three most serious constraints to economic development in South Africa (Parliament of the Republic of South Africa, 1994). These three constraints are also affecting females more than men. The unemployment rate of females for the period 2001 to 2011 has been consistently higher than that of men. The average unemployment rate for females is $32 \%$ compared to $26 \%$ of men during this period (Gender statistics, 2011).

The South African government realised that to address this problem they have to stimulate economic growth which would stimulate wealth and job creation. Entrepreneurial development is increasingly recognised as a tool in addressing South Africa's socio-economic challenges. In order to attain the objectives of economic growth through competitiveness on the one hand and employment generation and income redistribution on the other, policy attention has increasingly focussed on the promotion of the country's small, medium and micro-enterprises (SMMEs) economy (Rogerson, 2004).

Many researchers around the globe agree that there is a relationship between entrepreneurship and economic growth and development (Thurik \& Wennekers, 2004; Wong, Ho \& Autio, 2005). Entrepreneurs create new businesses, and new businesses in turn create jobs, intensify competition and may even increase productivity through technological change. High levels of entrepreneurship will thus translate directly into high levels of economic growth. Growth can be perceived inter alia as an increase in physical assets, bigger bank accounts, an increase in market share, the development of new products, entry into new markets, an increase in personal assets, greater profitability or a general increase in resources (Morrison, Been \& Shameen, 2003; Dockel \& Lighthelm, 2005). 
Due to the failure of the formal and public sector to absorb the number of job seekers in South Africa, attention has focussed on entrepreneurship and its potential for contributing to economic growth and job creation (Herrington, Kew \& Kew, 2008). The publication of the White Paper on the Development of Small Business in South Africa in 1995 was a clear indication that government realised the importance of developing entrepreneurship and small businesses (White Paper 1995).

Due to the high unemployment rate of females it is necessary to find ways to improve the levels of self-employment of women in the South African context. The government has accepted the importance of women in entrepreneurship; therefore the White Paper makes special reference to the development of female entrepreneurs. However, the Total Early-Stage Entrepreneurial Activity (TEA) of women in South Africa is below the TEA activities of women in other countries. According to the Gem report (Maas \& Herrington, 2006), South Africa's TEA of women of $4.83 \%$ is below the average of $7.72 \%$. In 2011 the overall TEA rate of South Africa was $8.1 \%$ which was still lower than other efficiencydriven economies with the female TEA rate being $6.9 \%$ which is clearly a huge improvement since 2006 (Herrington et al, 2011).

Development efforts in South Africa focus on providing financial as well as non-financial assistance. The Department of Trade and Industry (DTI) was entrusted to coordinate the implementation of government's support strategy to SMMEs through support initiatives for entrepreneurs (including female entrepreneurs) such as Seda, Khula, the Youth Development Agency, South African Micro Apex Fund, the National Empowerment Fund and the Industrial Development Corporation (White Paper, 1995).

Government has since 1994 devoted considerable resources to supporting small enterprises. However, a 2004 national survey of small enterprises has provided overwhelming confirmation that government fails to reach small enterprises. The survey established that small enterprises are either unaware of or do not use the services offered by government (Orford, Herrington \& Wood, 2004: 45). In the light of the failure of government support agencies to meet the needs of small business and the incapacity of these support institutions to raise awareness about their existence (Rogerson, 2004, Molapo, Mears \& Viljoen, 2008) it is important to determine how female entrepreneurs were affected.

Government had acknowledged the contribution that female entrepreneurs can make to alleviate unemployment through policy that can benefit them. It is therefore necessary to determine whether these benefits are only on paper or whether female entrepreneurs receive assistance. The main objective of this paper is to report whether the use of government support initiatives contributed to the growth of female businesses.

The literature review discussing growth, barriers facing female entrepreneurs and government initiatives will follow. The results of the survey of 111 female entrepreneurs are discussed and the article concludes with recommendations and directions for future research within SMMEs for female entrepreneurs.

\section{Literature Review}

\subsection{SME Growth}

Any entrepreneur would want his business to be a success. Success can be measured on the basis of various variables including turnover, profit and employment levels of the firm. The turnover of the firm will be investigated here. Growth makes a firm bigger. Growth is a multi -faceted phenomenon that is commonly associated with firm survival, achievement of business goals and success, or scaling up of activities (Dobbs \& Hamilton, 2007: Wickham 2006). Wickham (2006) stated that the entrepreneur must view the development and growth of their business from a financial, strategic, structural and an organisational perspective. The financial growth reflects growth in income, expenditure and profits; strategic growth in market presence and competitive advantage; structural growth in organisational form, process and structure and organisational growth in the organisation's culture and attitudes.

Crijins (2001) in his integrated model for business growth identified four success factors for business growth. The four factors are the availability of resources, the external environment, organisational factors and entrepreneurial orientation. The crux of the model is that that the first three factors create the potential for growth, but that growth will only take place if an entrepreneur has the correct entrepreneurial orientation to unlock the potential for growth. Morrison, Breen and Shameen (2003) concur that the human factor is considered to be the overwhelming force in obtaining business growth. If the entrepreneur is incompetent or does not have the desire to grow his business then no growth will take place. It is important for the entrepreneur to be aware of these factors and how these will impact on business growth strategies.

Even though entrepreneurs are aware of these factors they are faced with many challenges in growing their businesses. Darroch and Clover (2005) have identified eight dimensions of constraints on agribusiness SME survival and 
growth: a lack of access to services, funding constraints at start-up, lack of management capacity, in the enterprise, access to tender contracts, compliance costs associated with Vat and labour legislation, liquidity stress, lack of collateral and lack of institutional support. It is evident from these factors that they are in line with the broad classification in the literature of the factors as being internal and external (Morrison et. al., 2008; Niskanen \& Niskanen, 2005)

Growth can be achieved through various means but can also be hampered by various factors. In the light of these considerations it is necessary to look at the barriers that female entrepreneurs face.

\subsection{Barriers facing female entrepreneurs}

Running a business is very risky for any entrepreneur, even more so for women entrepreneurs who not only have to survive in a male-dominated environment but also often lack the education and training in this field. McClelland, Swail, Bell \& Ibbotson (2005) clearly stated that women confront a variety of challenges in developing and running a business and many argue that significant barriers still remain for women establishing and growing businesses. The current South African government focuses on the empowerment and development of previously marginalised communities. Simbwaye in Botha (2006) argued that women entrepreneurs in South Africa have been particularly disadvantaged in the past as they do not own any property which can be used as collateral on loans and need their husbands' permission to enter into financial arrangements. Consequently it is important to understand the constraints facing women entrepreneurs in developing countries and specifically in South Africa.

Botha (2014) states that women entrepreneurs face specific barriers, e.g.: limited access to finance, lack of support, negative prevailing socio-cultural attitudes, gender discrimination and bias, personal difficulties, lack of training and education and balancing family life and business. Hendricks (2003) identified the regulatory environment, education opportunities and systems, cultural factors, societal views and perceptions, management training and family responsibilities as the five most relevant challenges that female entrepreneurs face in South Africa.

Co, Groenewald, Mitchell, Nayager, Van Zyl and Visser (2006) have listed the following barriers women entrepreneurs face: discrimination, difficulty in obtaining credit, limited exposure to mathematics and finance, social bias, isolation from business networks, balancing home and work roles, developing a management style, negative selfperceptions, hostile environment, lack of business and management training and experience and few female role models.

Barriers of female entrepreneurs can be categorised under three broad categories namely personal development and responsibilities, access to resources and discrimination and social bias. However the effect of these barriers can be contracted by support structures that can contribute to more successful female business owners. Support institutions should be able to assist female entrepreneurs in identifying bottlenecks, while providing guidance and the necessary support to solve problems.

\subsection{Support for female entrepreneurs}

Hendricks (2003) remarked that although there have been dramatic changes in South Africa since 1994, particularly in the business environment there are still not enough women entrepreneurs. Research the world over has shown that many interventions need to be made to fast-track the development of women entrepreneurs. (Domeison, 2003; Welter, 2004; Sarri, \& Trihopoulou, 2005). The GEM 2006 summary results conclude: "The institutional environments that entrepreneurs operate in - political, legal and cultural - directly influence their activity and hence the course of economic development of the country" (Maas \& Herrington, 2006).

If the environment in which entrepreneurs operate directly influence entrepreneurial activity then an enabling environment is of critical importance for women entrepreneurs and will have an impact on the activity of women entrepreneurs. The use of entrepreneurial talent for productive purposes depends very much on the access to institutional support by entrepreneurs.

Support for women, as an emerging sector in the global business environment, according to the DTI report (DTI, 2005) is an important means of raising the level of entrepreneurship overall in society. According to Allen, Elam, Langowitz \& Dean (2007) investment in women entrepreneurship is an important way for countries to exponentially increase the impact of new-venture creation. Ignoring this proven potential of women's entrepreneurial activity means that countries put themselves at a disadvantage and thwart their opportunity to increase economic growth. It is therefore important that countries find ways to empower women's participation and success in entrepreneurship through sustainable and successful economic development.

The South African government in their efforts to develop entrepreneurship has entrusted the DTI to coordinate the implementation of governments' support strategy to SMME's and the following support initiatives for entrepreneurs 
(including female entrepreneurs) were put in place. Institutions such as the Small Enterprise Development Agency (SEDA), Khula Enterprise Finance Limited, South African Micro-Finance Apex Fund (SAMAF), state funded organisations such as the Industrial Development Corporation (IDC), the National Empowerment Fund (NEF), the National Youth Development Agency (NYDA) and provincial development corporations such and the Gauteng Enterprise Propeller (GEP) and the Gauteng Economic Development Agency are all developed to assist the South Africans government's efforts to develop entrepreneurship.

According to Rogerson (2004) a World Bank report argued that the White Paper (1995) has done an excellent job in creating a policy that is based on the particularities of South Africa. It is evident from the discussion above that the South African government has invested considerable resources into supporting small enterprises. Researchers have identified many shortcomings in the implementation of these support efforts by government.

Molapo, Mears and Viljoen (2008) have identified a number of shortcomings from the micro- and macroeconomic evaluation of small business support programmes during the period 1996 and 2003. They found the following:

(1) Both small business and government perceive that financial and non-financial institutions and agencies are not meeting the needs of the small business sector.

(2) Small firms are still excluded from funds and support for reasons that ranges from not being aware of the existence of support programmes to the fact that these programmes are not easily accessible. The reasons are inter alia that the cost of funding is too high and that the criteria for support are too strict.

Wadula (2003) and Chalera (2006) in Molapo et al. (2008) report that government admits that its financial and nonfinancial institutions are not meeting the needs of small business and that SEDA has become a wasteful bureaucracy and out of touch with SMMEs respectively. Berry et al. in Rogerson (2004) concurs that there is a general mistrust to external agencies among SMMEs on the one hand and the incapacity of support institutions to persuasively raise awareness about their existence and effectiveness on the other hand.

Naidoo and Hilton (2006) conducted a study on the access to finances for women entrepreneurs and surveyed 172 women across four provinces. The study was conducted in Cape Town, Pietermaritzburg, Polokwane and Durban. The study found that only 7 of the 172 respondents were aware of development institutions in their province and of their products and how to access them. In the entire sample only two women enjoyed support from a provincial financier. One obtained a loan and the other one received business planning support. A few women have heard of Khula Enterprise Finance, but were not sure what the institution did or offered. The business development services at SME-level surveyed in this study reflect a male/female usage ratio of 70/30. This is an indication that women entrepreneurs are far from being sufficiently supported in their entrepreneurial ventures.

\section{Research Methodology}

\subsection{Sample}

Quantitative data collection techniques and analysis procedures were used in the research design. The primary collection of data was done using the survey method through a web- based questionnaire which consisted of four sections. Section $B$ dealt with the nature of the business and covered questions one to ten. Section $C$ dealt with the awareness of government initiatives and services and included questions eleven to fourteen. Section D dealt with the biographical information and covered questions fifteen to seventeen.

\subsection{Measurement instrument}

The population of this research consisted of a list of 251 female entrepreneurs which was compiled by combining two lists: one list of 122 members of SAWEN in the Tshwane-area and 129 female entrepreneurs in the Tshwane-area on the GEP- database. Only 219 respondents could be reached and a total of 111 completed questionnaires were obtained. The response rate for this survey was $51 \%$ and deemed to be representative of the population.

Close-ended questions were used in this questionnaire with the respondent being able to choose from two or more fixed alternatives. Close-ended questions have the advantage of obtaining greater uniformity of measurement and therefore greater reliability since the respondent answers in a manner which fits the response category. In some cases a category that stipulated other/please explains, was provided to accommodate responses other than those listed. A fivepoint Likert scale was used in group B in the questionnaire. Likert rating scales were used because it allowed respondents to indicate a degree of agreement or disagreement or a level of importance of a set of statements concerning a particular object (Finn, Elliot-White \& Walton 2000). In question 5 the respondents had to indicate the 
importance they attach to each statement and in question 6 the respondents indicated the extent to which they agreed or disagreed with each statement.

The computer-assisted telephone interview (CATI) facility at the Bureau for Market Research at the University of South Africa was used. A CATI-facility consists of acoustically isolated interviewing carrels organised around supervisory stations. Each interviewer has a personal computer or terminal that is networked on the phone system and connected to the central processing unit (Cooper, 2014). Nine fully trained computer literate interviewers were used to conduct the interviews.

\subsection{Data analysis}

The web-based questionnaire automatically entered and saved the data to a computer file which was exported into an Excel spreadsheet from where statistical analysis was performed. Descriptive as well as inferential statistical analyses were used in the analysis of the data. Descriptive analysis was done to determine the frequency. Proportional testing measures whether the proportions are different.

The reliability was measured using Cronbachs Alpha for both questions 5 (listing 7 items) and 6 (listing 12 items). Question five registered a Cronbach's Alpha value of .553 and questions six a value of .771. The closer the Cronbach's Alpha value is to one the higher the reliability estimate of the instrument. It is clear that the instrument was reliable.

\section{Results}

The results will report on whether these female entrepreneurs were aware of the support initiatives of government and whether those that have received assistance have shown any growth in their businesses.

Table 1: Overall awareness of government initiatives and assistance received

\begin{tabular}{|c|c|c|c|c|c|c|c|c|c|c|c|c|}
\hline \multirow[t]{3}{*}{ Agency } & \multicolumn{6}{|c|}{ Aware } & \multicolumn{6}{|c|}{ Services received } \\
\hline & \multicolumn{2}{|c|}{ Yes } & \multicolumn{2}{|c|}{ No } & \multicolumn{2}{|c|}{ Total } & \multicolumn{2}{|c|}{ Yes } & \multicolumn{2}{|c|}{ No } & \multicolumn{2}{|c|}{ Total } \\
\hline & $\mathrm{N}$ & $\%$ & $\mathrm{~N}$ & $\%$ & $\mathrm{~N}$ & $\%$ & $\mathrm{~N}$ & $\%$ & $\mathrm{~N}$ & $\%$ & $\mathrm{~N}$ & $\%$ \\
\hline Khula & 88 & 79.3 & 23 & 20.7 & 111 & 100 & 5 & 5.7 & 83 & 94.3 & 88 & 100 \\
\hline SEDA & 89 & 80.2 & 22 & 19.8 & 111 & 100 & 20 & 22.2 & 70 & 77.8 & 90 & 100 \\
\hline NYDA & 97 & 87.4 & 14 & 12.6 & 111 & 100 & 10 & 10.3 & 87 & 89.7 & 97 & 100 \\
\hline SAMAF & 27 & 24.3 & 84 & 75.7 & 111 & 100 & 2 & 7.4 & 25 & 92.6 & 27 & 100 \\
\hline NEF & 54 & 48.6 & 57 & 51.4 & 111 & 100 & 2 & 3.7 & 52 & 96.3 & 54 & 100 \\
\hline GEDA & 43 & 38.7 & 68 & 61.3 & 111 & 100 & 2 & 4.5 & 42 & 95.5 & 44 & 100 \\
\hline GEP & 61 & 55.0 & 50 & 45.0 & 111 & 100 & 8 & 13.1 & 53 & 86.9 & 61 & 100 \\
\hline IDC & 48 & 43.2 & 63 & 56.8 & 111 & 100 & 4 & 8.3 & 44 & 91.7 & 48 & 100 \\
\hline
\end{tabular}

Analysis of the data (table 1) revealed that fifty seven percent (57\%) of the respondents in the study were aware of the support initiatives of government, and that there is a raised awareness of some of the government's support initiatives. The NYDA, SEDA and Khula recorded the highest level of awareness amongst the respondents. The results also further revealed that even though the respondents were aware of the various support initiatives only a small percentage (9.4\%) of the respondents have actually received support. This is line with the results of Naidoo and Hilton (2006:6) who have found that only one respondent in their study received financial assistance

Table 2: Descriptive statistics

\begin{tabular}{|c|c|c|c|c|c|}
\hline \multirow{2}{*}{ Variables in the module } & \multicolumn{4}{|c|}{ Business Growth } \\
\cline { 3 - 6 } & & \multicolumn{2}{|c|}{ Growing } & \multicolumn{2}{|c|}{ Not Growing } \\
\cline { 3 - 6 } & $\mathbf{N}$ & $\%$ & $\mathbf{N}$ & $\%$ \\
\hline \multirow{3}{*}{ Have you received any assistance from Khula } & Yes & 4 & 10.0 & 1 & 2.1 \\
& No & 36 & 90.0 & 47 & 97.9 \\
\cline { 2 - 6 } & Total & 40 & 100 & 50 & 100 \\
\hline \multirow{2}{*}{ Have you received any assistance from Seda } & Yes & 8 & 20.0 & 12 & 24.0 \\
& No & 32 & 80.0 & 38 & 76.0 \\
\cline { 2 - 6 } & Total & 40 & 100 & 50 & 100 \\
\hline
\end{tabular}




\begin{tabular}{|c|c|c|c|c|c|}
\hline \multirow{2}{*}{ Have you received any assistance from NYDA } & Yes & 7 & 16.7 & 3 & 5.5 \\
& No & 35 & 83.3 & 52 & 94.5 \\
\cline { 2 - 6 } & Total & 42 & 100 & 55 & 100 \\
\hline \multirow{3}{*}{ Have you received any assistance from SAMAF } & Yes & 1 & 8.3 & 1 & 6.7 \\
& No & 11 & 91.7 & 14 & 93.3 \\
\cline { 2 - 6 } & Total & 12 & 100 & 15 & 100 \\
\hline \multirow{3}{*}{ Have you received any assistance from NEF } & Yes & 2 & 6.9 & 0 & 0.0 \\
& No & 27 & 93.1 & 25 & 100.0 \\
\cline { 2 - 6 } & Total & 29 & 100 & 25 & 100 \\
\hline \multirow{2}{*}{ Have you received any assistance from GEDA } & Yes & 1 & 3.8 & 1 & 5.6 \\
& No & 25 & 96.2 & 17 & 94.4 \\
\cline { 2 - 6 } & Total & 26 & 100 & 18 & 100 \\
\hline Have you received any assistance from GEP & Yes & 5 & 18.5 & 3 & 8.8 \\
\hline Have you received any assistance from IDC & No & 22 & 81.5 & 31 & 91.2 \\
\cline { 2 - 6 } & Total & 27 & 100 & 34 & 100 \\
\hline & Yes & 2 & 9.1 & 2 & 7.7 \\
\cline { 2 - 6 } & No & 20 & 90.9 & 24 & 92.3 \\
\cline { 2 - 6 } & Total & 22 & 100 & 26 & 100 \\
\hline
\end{tabular}

In Table 2 the growth index was determined by the turnover of the business of the past year. The sales turnover is a more comprehensive variable because it involves both demand and supply factors that impact on the business. The independent variables used as explanatory variables of the growth experience were whether assistance was received from the various government institutions. Of the total of 111 respondents 42 per cent indicated a growth in turnover, 32 per cent showed a decline in turnover and 26 per cent indicated their turnover remained the same.

According to the results in Table 2 the majority of the respondents did not receive any assistance from these government institutions. It is evident from the results that on average $88 \%$ of respondents' businesses experienced growth even though they have not received assistance from any of the government institutions. The question that immediately came to mind was whether government support initiatives are of any value to female entrepreneurs. The results also reflected that those who did get assistance $13 \%$ showed growth in their businesses. It is also noticeable that an average of $8 \%$ of respondents did not experience any growth even though they did get assistance from these government institutions. Further analysis was done using the two sample test of proportion to determine whether the proportions between yes we have received and no we have not received any assistance were different in respect of business growth.

Table 3: Two sample test of proportion

\begin{tabular}{|l|c|c|}
\hline & Yes & No \\
\hline Have you received assistance from Khula & 0.799 & 0.117 \\
\hline Have you received assistance from SEDA & 0.834 & 0.688 \\
\hline Have you received assistance fromNYDA & 0.632 & 0.087 \\
\hline Have you received assistance from SAMAF & 0.874 & 0.086 \\
\hline Have you received assistance from NEF & & 0.181 \\
\hline Have you received assistance from GEP & 0.709 & 0.299 \\
\hline Have you received assistance from GEDA & & 0.794 \\
\hline Have you received assistance from IDC & & \\
\hline
\end{tabular}

Table 3 shows the results from the two sample test of proportion measuring whether the difference between the proportions yes and no is significant. In both columns certain values could not be attained because of the degree of missing values. The missing values can be attributed to the fact these female entrepreneurs were not aware of these support institutions and therefore did not respond. According to the results in Table 3 the proportion of female entrepreneurs who received assistance and indicated that their business is growing is not statistically different from those who said that their business is not growing. This clearly indicates that growth was not directly influenced by the receipt of assistance from government support institutions. These findings clearly confirm that these female entrepreneurs would make a success of their businesses irrespective whether they have received assistance from government support institutions. Another factor that could attribute to the growth of their businesses is perhaps the fact that in this study it was found that these respondents clearly indicated that the factors that they view as very important in their motivation to 
become entrepreneurs are pull (opportunity) factors such as: the need to be an achiever (88.3\%), desire to have your own business (76.6\%) and to enjoy new opportunities (60.4\%). The push factor, obligation to earn an income, also scored high $(75 \%)$ but overall the pull factors influenced their decision to run their own business, which is contrary to the widely held belief that women start businesses for reasons other than gaining power, riches and influence.

\section{Conclusions and Recommendations}

The contribution that female entrepreneurs can make to the alleviation of unemployment and economic growth has received some significant attention in recent years. Changes to and adoption of new policies have attempted to create a supporting environment in which female entrepreneurs could function optimally. The South African government has with the publication of the White Paper in 1995 showed commitment to support female entrepreneurs with the introduction of certain support initiatives.

Previous research has proved that these government support initiatives have failed to adequately support female entrepreneurs (Naidoo and Hilton 2006, Molapo et al. 2008, Rogerson, 2004). The results of these studies identified many shortcomings in the implementation of these support initiatives by government ranging from accessibility, lack of raising awareness of their existence, not meeting the financial and non-financial needs of small business and a general mistrust of SMME's to external agencies. The results of this study provided insights into the current situation regarding the providing of support to female entrepreneurs as well as the impact that the received support had on their business growth.

The results of the current research suggest that accessibility has improved and that more female entrepreneurs have received assistance compared to a previous study, but the situation is far from satisfactory. This improvement in the number of female entrepreneurs that have received assistance might be because they are more aware of the existence of these support initiatives or perhaps that the criteria for funding are less stringent.

The results indicate that the minority of the respondents (30 of 111) got assistance from government support structures. It was also evident from the results that the majority of the respondents who did not receive any assistance from these government institutions showed growth in their businesses. The low utilisation of the initiatives is in line with the findings of previous studies and it clearly shows that government has not yet fully achieved the objective of the White Paper with regards to the advancement of women in business sectors. The results therefore provide an indication that government should do more to assist female entrepreneurs in their ventures. Support institutions should also mentor the entrepreneurs to ensure that the assistance is valued which could then lead to growth in their businesses.

\section{Recommendations}

- Business support should take into account the differing needs of different types of small enterprises and provide distinct service packages for the different target groups.

- Coherent support services have to guarantee that enterprises can easily access a service package which covers all the main management functions.

\section{Limitations}

This study was only done in the Tshwane area. Future research would be useful to extend the research to the rest of the country and more so to the rural areas.

\section{References}

Adams, M. (2014). Networking and support. In: Nieman, G. \& Nieuwenhuizen, C. (eds) Entrepreneurship: A South African Perspective. (3rd ed). Pretoria: Van Schaik.

Allen,E., Elam, A., Langowitz, N. \& Dean, M. (2007). Global Entrepreneurship Monitor: Report on Women and Entrepreneurship. The Centre for Women's Leadership: Babson College.

Anon. [Online] Available from: http:///www.youthportal.org.za. Accessed on 2008/10/0.

Botha, M. (2006). Measuring the effectiveness of the women entrepreneurship programme, as a training intervention on potential, startup and established women entrepreneurs in South Africa. Unpublished doctoral thesis. Pretoria: University of Pretoria. [Online] Available from UPETD: $h$ ttp://upetd.up.ac.za/thesis/available/etd

Botha, M. (2014). The entrepreneur. In: Nieman, G. \& Nieuwenhuizen, C. (eds) Entrepreneurship: A South African Perspective. (3rd ed). Pretoria: Van Schaik. 
Co, M.J., Groenewald, J., Mitchells, B., Nayager, T., Van Zyl, J. \& Visser, K. (2006). Entrepreneurship (Fresh Perspectives). Pearson: Prentice Hall.

Cooper, D.R. (2014). Business Research Methods. (12th ed). New York: McGraw Hill.

Crijns,H. (2001). De Durf om te Ondernemen: Nuwe Aspecten van Ondernemerschap en Groeimanagement Tielt: Lannoo.

Darroch, M. \& Clover, T.A. (2005). The effects of entrepreneurial quality on the success of small, medium and micro agri-businesses in Kwazulu-Natal, South Africa, Agrekom, 44(3): 321-343.

Department of Trade and Industry. A Special Report (2005). South Africa; Women Entrepreneurs: A Burgeoning force in our economy. Department of Trade and Industry, South Africa.

Dobbs, M. \& Hamilton, R.T. (2007). Small business growth: recent evidence and new directions, International Journal of Entrepreneurial Behaviour \& Research, 13(5): 296-322.

Döckel, J. A., Lighthelm, A. A. (2005). Factors responsible for the growth of small businesses, South African Journal of Economic and Management Sciences, 8(1): 54-62.

Domeisen, N. (2003). Canada releases report on women entrepreneurs. International trade forum, 4.

DTI. 1995. White Paper on National Strategy for the Development and Promotion of Small business in South Africa. Notice 213 of 1995. [Online] Available from: http://www.info.gov.za/whitepapers/1995/smallbus.htm [Downloaded: 2007-03-08].

Finn, M., Elliot-White, M. \& Walton, M. (2000). Tourism and leisure research method: data collection, analysis and interpretation. Harlow: Longman.

Hendricks, L. (2003). Enhancing the role of women in economic development. A DTI Special Report. [Online] Available from: http://www.thedti.gov.za/publications (accessed on 2009/07/30).

Hendricks, L. (2003). Fast tracking women entrepreneurs in developing countries. [Online] Available from: http://www.dti. gov.za/article/article (accessed on 2009/10/06).

Herrington, M., Kew, J. \& Kew, P. 2008, Global Entrepreneurship Monitor: South African Report 2008. UCT Centre for Innovation and Entrepreneurship. Cape Town: University of Cape Town.

Herrington, M., Kew, J.,Simrie, M \& Turton, N . 2011, Global Entrepreneurship Monitor: South African Report 2011. UCT Centre for Innovation and Entrepreneurship. Cape Town: University of Cape Town.

Maas, G \& Herrington, M. (2006). Global Entrepreneurship Monitor: South African Report 2005. UCT Centre for Innovation and Entrepreneurship. Cape Town: University of Cape Town.

McClelland, E., Swail, J., Bell, J. \& Ibbotson, P. (2005). Following the pathway of female entrepreneurs. A six-country investigation. International Journal of Enterpreneurial Behaviour and Research, 11(2):84-107

Molapo, S., Mears, R. R. \& Viljoen, J. M. M. (2008). Development and reforms in small business support institutions since 1996. Acta Commercii. University of Johannesburg

Morrison, A., Breen, J. \& Shameen, A. (2003). Small business growth: intension, ability and opportunity, Journal of Small Business Management, 41(4): 417-425.

Naidoo, S. \& Hilton, A. (2006). Access to finance for women entrepreneurs in South Africa. Finmark Trust.

Niskanen, M. and Niskanen, J. (2005). The determinants of firm growth in small and micro firms. - Evidence on relationship lending effects', paper presented at the Social Science Research Network Entrepreneurship and Finance Conference, 6-8 March 2005.

Orford, J., Herrington, M. \& Wood, E. (2004). Global Entrepreneurship Monitor: South African Executive Report. UCT Centre for Innovation and Entrepreneurship. Cape Town: University of Cape Town.

Rogerson, C.M. (2004). The impact of the South African government's SMME programmes: a ten year review (1994-2003). Development Southern Africa, 21(5):765-874.

Sarri, K. \& Trihopoulou, A. (2005). Female entrepreneur's personal characteristics and motivation: a review of the Greek Situation. Women in Management Review, 20(1):24-36.

South Africa. (2004). National Small Business Amendment Act 2004.Government Gazette. [Online] Available from: http://www.info.gov .za/gazette/acts/2004

South Africa. (2008). National Youth Development Agency Act, No 54 of 2008. [Online] Available from: http://www.pmg .org.za/files/bills081223a54-08.

Statistics South Africa. (2011). Gender statistics in South Africa, Pretoria, Government Printers.

Thurik, R \& Wennekers, S. (2004). Entrepreneurship, small business and economic growth. Journal of Small Business and Enterprise Development, 11(1):141-149.

Welter, F. (2004). The environment for female entrepreneurship in Germany. Journal of Small Business and Enterprise Development, 11(2):212-221.

Wickham, P. (2006). Strategic Entrepreneurship. (4th ed). Harlow: Pearson Education Limited.

Wong, P.K., Ho, Y.P. \& Autio, E. (2005). Entrepreneurship, innovation and economic growth: Evidence from Gem data. Small, 24:335350. 